\title{
THE DYNAMICS OF TIME SERIES OF REAL ESTATE PRICES ${ }^{1}$
}

\author{
Miroslaw Belej, PhD \\ Faculty of Geodesy, Geospatial and Civil Engineering \\ University of Warmia and Mazury in Olsztyn \\ e-mail:caprio@uwm.edu.pl
}

\section{Slawomir Kulesza, PhD}

Faculty of Mathematics and Informatics

University of Warmia and Mazury in Olsztyn

e-mail:kulesza@matman.uwm.edu.pl

\begin{abstract}
The presented research aims to contribute to the concerns regarding the evolutionary dynamics of the real estate market, seen as an open system flowing from one equilibrium state into another. In such quasi-stable states, real estate markets are thought to change only slightly with elapsed time, but occasionally, a sudden jump, during which the markets undergo changes of structural origin, might occur as well. Hence, the paper contains an analysis of the dynamics of time series of housing prices in order to distinguish between processes of different time scales. Research was performed assuming $a$ priori distributions of the variables, and using the autocorrelation function together with the partial autocorrelation function for detailed data analysis.
\end{abstract}

Key words: time series, dynamics, real estate market.

JEL Classification: C51, R30, R32.

Citation: Belej M., Kulesza S., 2015, The Dynamics of Time Series of Real Estate Prices, Real Estate Management and Valuation, Vol. 23, No. 4, pp. 35-43.

DOI: $10.1515 /$ remav-2015-0034

\section{Dynamical systems}

Economic phenomena can be thought of as processes occurring in a three-dimensional state-space $\mathrm{R}^{3}$ with a set of coordinates $(x, y, z)$, which allows us to extract key spatial characteristics of the studied problem. In such a case, however, the lapse of time is a priori considered to be an insignificant factor to the dynamics of the system, hence the analysis of empirical data recorded in a given time interval requires that their main attributes be studied either (1) at a given point in time, or (2) after some averaging over the time interval. The first approach makes use of one of numerous methods for detrending time series, which adjust the values in a data sequence prior to their comparison. Studies of the housing market are usually carried out using transaction prices per square meter updated at an arbitrary moment in time. Several examples of such analysis can be found in: CELLMER (1999), HOZER (1999), CZAJA (2001), ADAMCZEWSKI (2002), BITNER (2003), BUDZYŃSKI (2010). An alternative approach to this problem ignores the order of the sampled data, assuming implicitly that the observables vary insignificantly over time or that the time scale of the data is small compared to the specific inertia of the system.

1 This work was supported by a grant from the National Science Centre (NCN) number DEC 2012/07/B/Hs4/03267 
Time-independence of the dynamics of economic phenomena actually implies modeling under stationary conditions, whereas in reality, our surroundings are constantly changing, and hence such an assumption could lead to substantially biased results. Therefore, three-dimensional Euclidean space and one-dimensional time are unified into a four-dimensional space-time continuum. The need for time-variant models in economic research was first proposed a long time ago in the work of MILL (1965), who stressed that economic problems could be analyzed more deeply using the tools of classical dynamics upon introduction of the time variable.

Since the beginning of economic research, the essential question of whether dynamical phenomena are just small deviations from the equilibrium, or reflect an intrinsic property of the economic processes still remains unanswered (DOMAN, DOMAN 2004). Dynamical analysis tries to follow the evolutionary paths of the systems to study the specific properties of their asymptotic behavior: stable orbits, smooth transitions, and equilibrium states. According to BRZESZCZYŃSKI and KELM (2002), such an approach allows us to estimate the degree of instability of the system, and make forecasts regarding its long-term balance. Once the market processes can be divided into short- and long-term ones, established cause-and-effect relationships and symptomatic dependencies might be interpreted ambiguously. On that theoretical background, a growing number of studies of the real estate market are exploring dynamical aspects of economic phenomena together with a detailed analysis of their origin, e.g.: FORYŚ (2010), BRZEZICKA (2013), TROJANEK (2013), DitTMAN (2013), RENIGIER-BiŁOZOR et al. (2014), DRACHAL (2014) and КОКOT (2014).

The paper is devoted to the dynamical analysis of housing prices in Olsztyn from the beginning of 2001 until the end of 2011. On that base, several conclusions about the nature of the housing market and occurring processes are drawn, taking samples of housing prices into consideration.

\section{Stationarity and non-stationarity in time series}

Time-series analysis adopts interdisciplinary scientific methods from the theory of econometrics and multidimensional statistical analysis. The obtained results provide important characteristics of dynamical systems in various areas of research: biology, chemistry, sociology, economics etc. Among others, issues concerning time series were described by CHATFIELD (1975), KeNDALL (1976), LANGE (1975) and ZeLIAŚ (1984).

A time series reflects the evolution of a studied system acted upon by outside forces of diverse characteristics in terms of their amplitude and time of duration (GRUDKOWSKA, NEHREBECKA 2009). In turn, RABIEJ (2012) states that each time series contains queued information on the prices under study taken at arbitrary time steps. According to MILO (1990), a time series comprises a sequence of measured events of a quantity. In a strict mathematical sense, he defines the time series $y=\left[y\left(t_{1}\right) \ldots y\left(t_{n}\right)\right]$, $y \in R^{n}$ with respect to time $t$ as an ordered set of samples of a random variable $Y\left(t_{1}\right), \ldots Y\left(t_{n}\right)$, that is the discrete realization of a real, random process $Y$.

Time-series analysis can be divided into three basic tasks:

- descriptive characteristics of the data sequence involving, among others, the arithmetic mean, median, variance and standard deviation,

- measures of variability in time using, for example, increments and indexes,

- decomposition of a series into: a long-term trend, cyclic fluctuations, and random changes.

Time series in economics are distinct from those in other scientific fields in that they are influenced by a combination of deterministic and random factors. Assuming that the real time series represent indicators of the system dynamics, analyzed data might contain a number of measurable quantities, which reflect various aspects of market behavior. On the other hand, they can be seen as samples of random processes occurring in a state space. Because the points in such a space are parameterized with time, the resulting time series are actually associated with stochastic processes (DOMAN, DOMAN 2004) and exhibit a unique pattern. Depending on the particular situation, the pattern becomes more or less regular as it is the sum of a deterministic component and an interfering noise (SZAFRAŃSKI 2015).

The analysis of the distribution function of a random variable and checking for its stationarity/non-stationarity are the key elements of the time-series decomposition. A stochastic process is said to be non-stationary if parameters of a probability distribution vary over time. For this reason, non-stationary processes have a time-varying mean and/or a time-varying variance. The former property is responsible for the quasi-monotonic evolution of a time series towards higher or smaller values. By contrast, the latter property makes the time series highly fluctuating. Non- 
stationary time series of this type are, for example, series of prices of material goods, in which short intervals of large changes in variance (bubbles) are intertwined with those of slow but steady changes in the mean. It is also possible that the variance in a given range strongly depends on previous data giving rise to a large positive feedback, which may influence the time series even in the far future. In such a case, market sentiments and expectations may establish a breeding ground for economic crises that trigger price bubbles.

Unfortunately, the analysis of non-stationary data by statistical inference can produce misleading results. This applies, in particular, to seemingly significant statistics obtained after the completion of significance tests for model variables. As mentioned earlier, most empirical data in economic studies form non-stationary time series, hence they need to be transformed into a stationary sequence prior to analysis. This can be done using various detrending algorithms, which, in general, rely on separating a linear or nonlinear deterministic trend from raw data. Alternatively, non-stationary time series can be turned into stationary ones by computing the difference between two consecutive entries of the sequence.

A stochastic process is said to be stationary if its subsequent samples remain uncorrelated, and probability distributions of measured quantities are time-invariant. In general, perfectly stationary time series are hardly ever encountered; therefore, one can distinguish strong and weak stationarity. A time series exhibits weak stationarity if and only if:

- its expected value is time-invariant:

$$
\forall_{\mathrm{t}} \mathrm{E}\left(\mathrm{X}_{\mathrm{t}}\right)=\mu
$$

- its variance is finite and time-invariant:

$$
\forall_{\mathrm{t}} \mathrm{E}\left(\mathrm{X}_{\mathrm{t}}^{2}\right)=\sigma^{2}<\infty
$$

- its autocovariance depends only on the lag between samples:

$$
\forall_{\mathrm{t}, \mathrm{k}, \mathrm{s}} \operatorname{cov}\left(\mathrm{X}_{\mathrm{t}}, \mathrm{X}_{\mathrm{t}+\mathrm{k}}\right)=\operatorname{cov}\left(\mathrm{X}_{\mathrm{t}+\mathrm{s}}, \mathrm{X}_{\mathrm{t}+\mathrm{k}+\mathrm{s}}\right)
$$

As a rule, if a random variable with normal distribution is weakly stationary, then it is strongly stationary as well. To verify the fulfillment of the above conditions for a process with a normally distributed variable, basic descriptive statistics need to be computed. In other cases, instead of testing a large variety of particular distribution functions, it is sufficient to check for the time-invariance of the parameters of the multidimensional distribution of a random variable (SZAFRAŃSKI 2015). This can be done by the analysis of the autocorrelation function (ACF) and its partial autocorrelation function (PACF). ACF is equivalent to a normalized autocovariance function, which is sensitive to functional dependencies between samples in a sequence:

$$
\operatorname{corr}\left(\mathrm{X}_{\mathrm{t}}, \mathrm{X}_{\mathrm{t}+\mathrm{k}}\right)=\frac{\operatorname{cov}\left(\mathrm{X}_{\mathrm{t}}, \mathrm{X}_{\mathrm{t}+\mathrm{k}}\right)}{\operatorname{var}\left(\mathrm{X}_{\mathrm{t}}\right)}
$$

An autocorrelation plot, also known as an correlogram, can be useful in verifying the stationarity of time series. Correlograms of stationary processes should quickly fall to zero with increased sample lag. By contrast, correlograms of processes with a time-varying mean could remain non-zero even for large time-shifts, while those of processes with time-varying variance might oscillate between extreme values.

The plots of the ACF and PACF functions might also be helpful in detecting characteristic patterns of deterministic components of stationary time series using linear ARMA models. The notation ARMA $(\mathrm{p}, \mathrm{q})$ refers to the model with autoregressive (AR) $\mathrm{p}$ terms and moving-average (MA) $\mathrm{q}$ terms. The first term describes the influence of past outputs of the series, that is represents the feedback. The order $\mathrm{p}$ of such a process can be determined from the PACF, which takes $\mathrm{p}$ non-zero values, and then drops down to zero. At the same time, the ACF plot vanishes exponentially. Unlike the AR part, the MA takes q previous samples of a random variable to generate an output. Its order can be determined from the ACF function, which takes q subsequent non-zero values, with the PACF exponentially approaching zero. An example of an AR process is a random walk, while that of MA - white noise. 


\section{Dynamical analysis of housing prices}

\subsection{Data description}

Time series of economic data are generated by random variables sampled at a wide range of periods that extends from a fraction of a second to years of observations. In time series specific of the real estate market, the delay between two consecutive samples is of the order of a quarter, but no less than a month (Trojanek 2008, DitTman 2012, Goetzmann, Peng, Yen 2012, Belaire-Franch, Opong 2013). What is worse, the diversity of attributes characterizing the objects of the transactions imprints inhomogeneity on the series making direct comparison of different markets impossible. When doing so, analyzed housing data series are previously averaged using, for example, the arithmetic mean or the median. Even though averaging introduces additional numerical errors, the benefits of the dynamical analysis of housing prices outweigh the costs of increased uncertainty.

The analysis involves a set of around 11,000 entries of transaction prices of housing properties in Olsztyn from 2001 to 2011, recorded in the Registry of Prices and Values in the Olsztyn City Office. The prices were first averaged monthly and recalculated with respect to the housing area in order to obtain the transaction price per square meter. The left plot in Fig. 1 shows a time series of such prices, whereas the right one - its first differences.
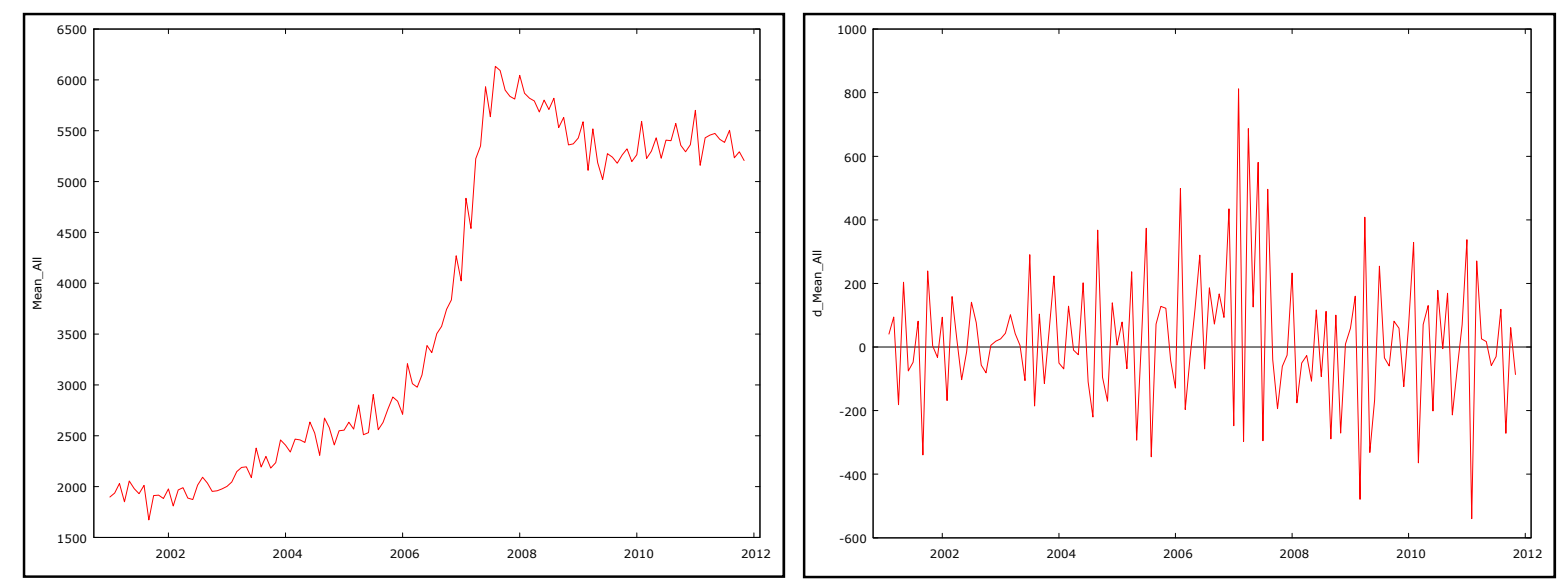

Fig. 1. Plots of the monthly-averaged transaction prices per square meter in Olsztyn from 2001 until 2011 (left), and its first differences (right). Source: own study.

At first glance, the plot of time series of averaged housing prices exhibits highly dynamic behavior. Between 2007 and 2008, housing prices grew on an unprecedented scale, with increases of up to 100 per cent from year to year, blowing a housing bubble. At that time, the housing market and its economic environment underwent a large transition of structural origin, followed by stepwise evolution towards a new equilibrium state. Basic descriptive statistics of the presented data and its first differences have been listed in Table 1 as Olsztyn_All and d_Olsztyn_All, respectively.

Table 1

Basic descriptive statistics

\begin{tabular}{cccccc}
\hline & Mean & Median & Minimum & Maximum & $\begin{array}{c}\text { Standard } \\
\text { deviation }\end{array}$ \\
\hline Olsztyn_All & 3789.2 & 3317.4 & 1672.5 & 6132.8 & 1568.2 \\
\hline d_Olsztyn_All & 25.471 & 17.650 & -540.26 & 812.08 & 214.53 \\
\hline & $\begin{array}{c}\text { Coef. of } \\
\text { variation }\end{array}$ & Skewness & Kurtosis & $\begin{array}{c}\text { Percentile } \\
\mathbf{5} \%\end{array}$ & $\begin{array}{c}\text { Percentile } \\
\mathbf{9 5 \%}\end{array}$ \\
\hline Olsztyn_All & 0.41387 & 0.098039 & -1.7628 & 5851.0 & 3135.6 \\
\hline d_Olsztyn_All & 8.4224 & 0.55594 & 1.5270 & -321.35 & 420.02 \\
\hline
\end{tabular}

Source: own study.

Closer inspection of basic descriptive statistics draws attention to the range of data $(4460.3$ $\left.\mathrm{PLN} / \mathrm{m}^{2}\right)$, that is the difference between the highest $\left(6132.8 \mathrm{PLN} / \mathrm{m}^{2}\right)$ and lowest $\left(1672.5 \mathrm{PLN} / \mathrm{m}^{2}\right)$ 
values in the studied interval. Such a large difference might reflect extraordinary stresses induced within the housing market by outside forces, which were released in the process of rapid balancing towards a new equilibrium state. The obtained coefficient of variation equal to 0.41387 confirms the hypothesis that the housing market is out of balance. Skewness approaches 0.098 , which means that the time series is positively skewed due to the sharp cut-off of transaction prices at lower levels. The first differences are much more skewed (0.55594) due to the aforementioned increase in housing prices. Both series exhibit similar, although opposite, values of kurtosis. Housing prices turn out to be platykurtic (-1.7628), while the first differences - leptokurtic (1.5270).

Fig. 2 presents the histograms of the density distribution functions estimated using the kernel density function. Averaged transaction prices exhibit a bimodal profile, whereas the first differences closely follow the Gaussian characteristics. Hence, the time series of the first differences can be thought of as a sample of a stationary stochastic process.
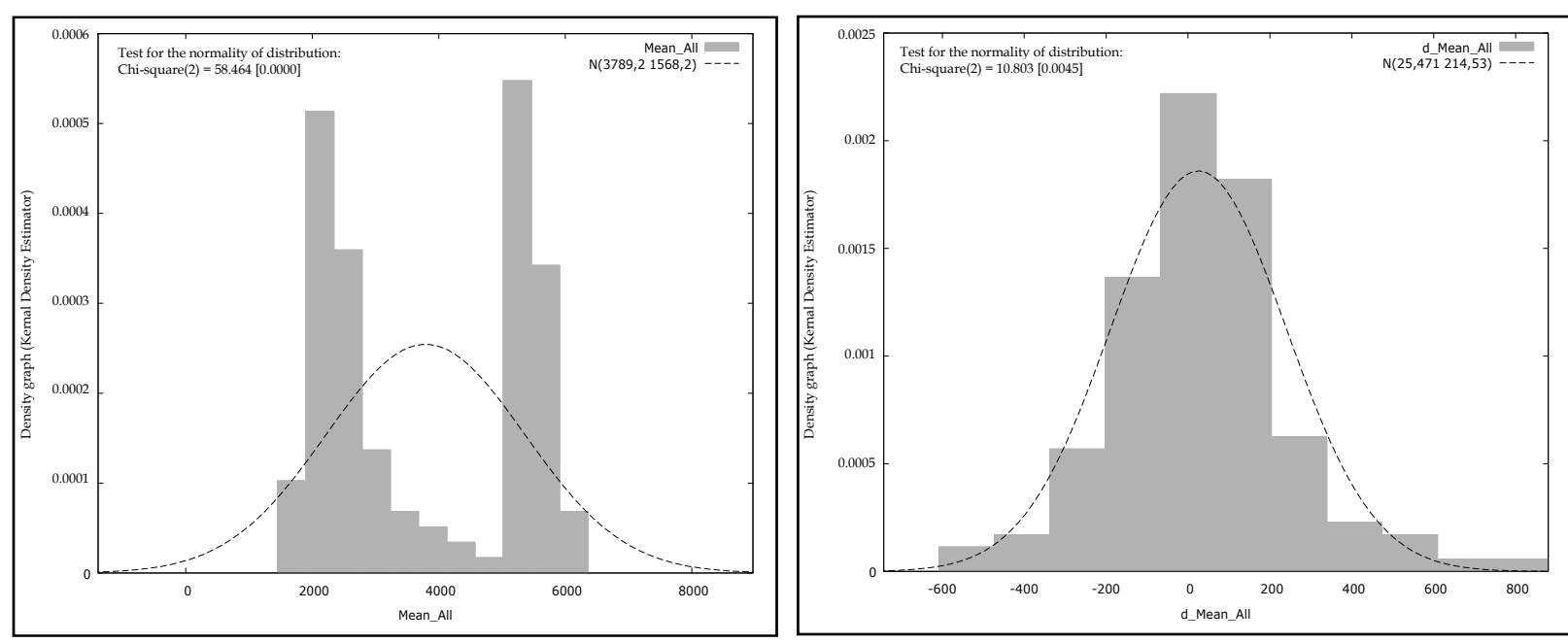

Fig. 2. Histograms of transaction prices for the mean (left) of housing prices and its first differences (right). Source: own study.

\subsection{Stationarity of housing prices}

This paper presents the results of analyses undertaken to support the suggestion that the evolution of the housing market is composed of two intertwined intervals: (A) laminar, long-term changes, and (B) turbulent, short-term bubbles. The housing bubble in Poland is commonly believed to have occurred between 2007 and 2008, depending on the local housing market, but the reduction of its duration period to a given interval seems inappropriate. Fig. 1 shows that even though transaction prices increased mostly in 2007, the changes were in fact triggered much earlier. Further studies are, therefore, aimed at establishing critical points at which the transition between laminar and turbulent regimes appears. This can be done using the ACF and PACF functions. Fig. 3 shows the plots of these functions for the analyzed time series of housing prices.

According to previous statements, the correlogram for the stationary process should quickly vanish to zero with increasing lag; however the plot seen in Fig. 3 exhibits a different behavior. It slowly vanishes, drifting between extreme values, which suggests that the entire time series under study reflects a non-stationary process. However, it can be split into almost stationary (A) and nonstationary (B) sub-series, respectively corresponding to laminar and turbulent market evolution. In the first range, changes in the housing market are caused by random oscillations around the equilibrium state, whereas in the later, they are determined in the course of a random walk process. Under these circumstances, the following sub-series are proposed, separated by the transition points between A and $B$ regimes:

- from January 2001 until June 2003,

- from July 2003 until November 2008,

- from December 2008 until December 2011.

For better clarity, Fig. 4 exhibits the plots of the ACF and PACF for data from the first interval. Note that the sub-series now appear stationary due to the extremely low number of entries that are 
significantly different from zero. Only the first elements meet this requirement, hence both AR and MA parts represent first order processes, as in white noise.

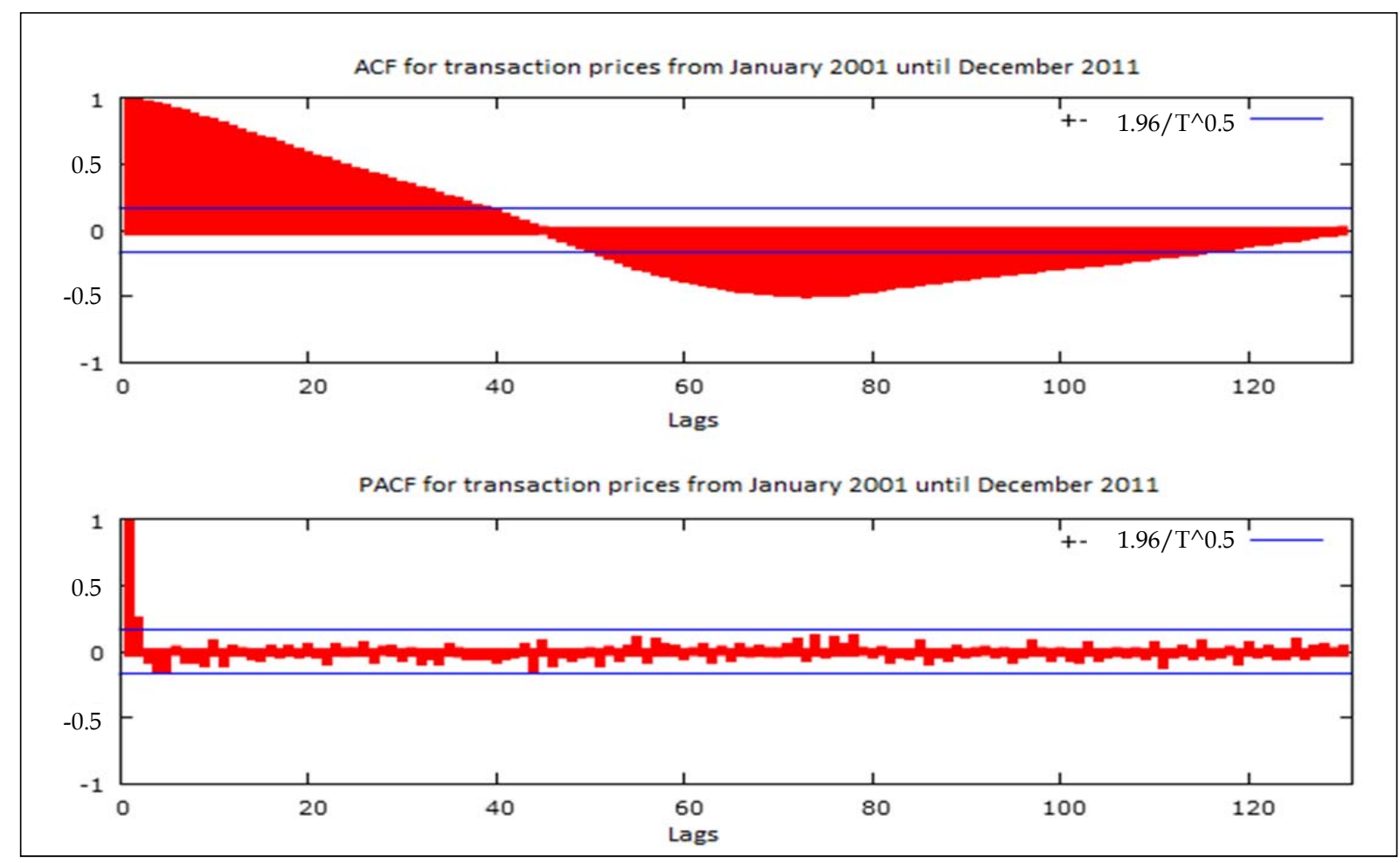

Fig. 3. The plots of the ACF (upper) and PACF (lower) functions of a time series of housing prices. Source: own study.

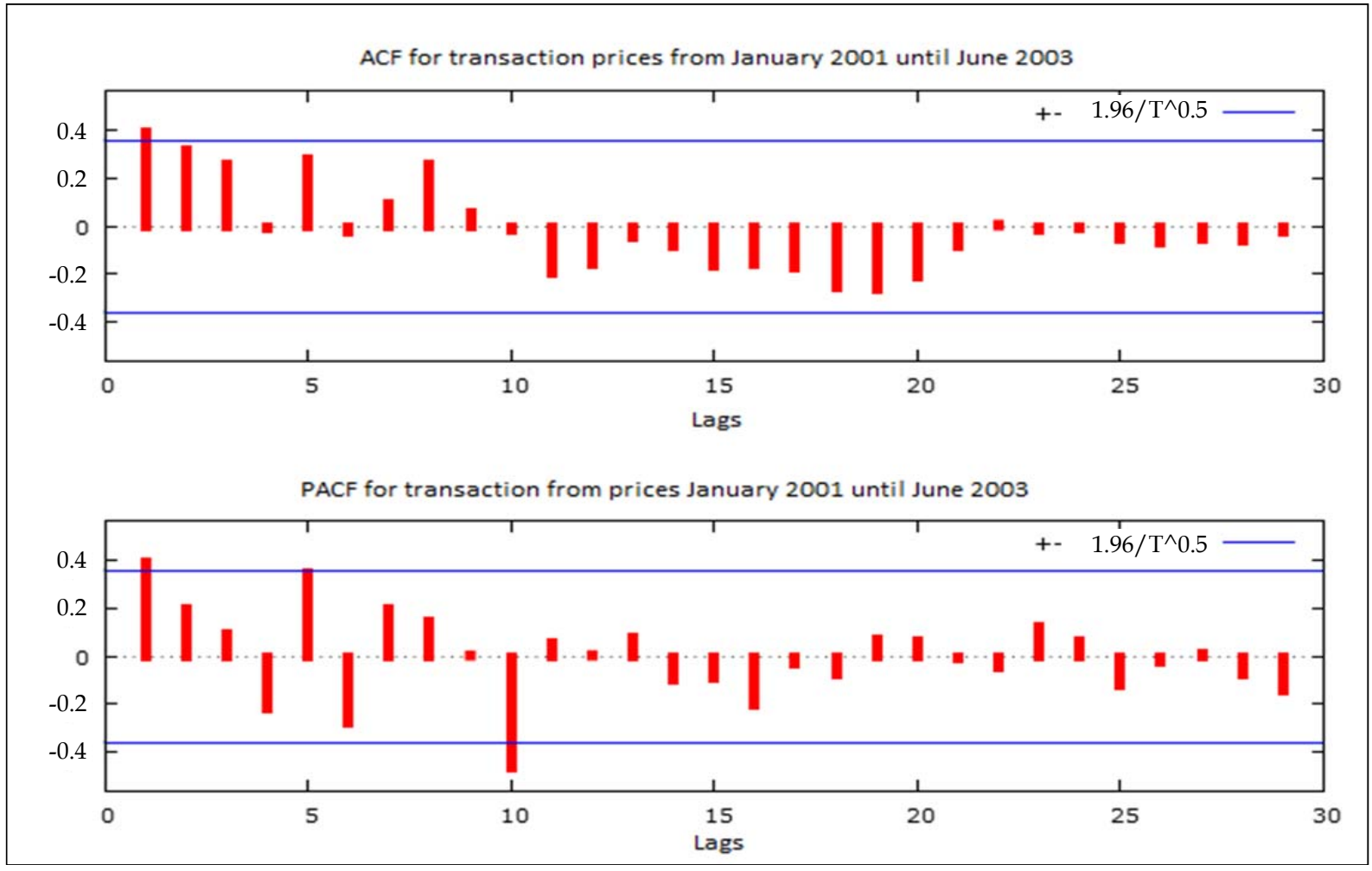

Fig. 4. Plots of the ACF (upper) and PACF (lower) functions for the sub-series from January 2001 until June 2003. Source: own study.

Averaged transaction prices in the first sub-series are likely to overlap with the equilibrium level prices, and the market is reduced to a short-memory system. The influence of previous outputs 
(housing prices) and inputs (agglomerate random variable) might therefore be neglected. Current prices are set ad hoc without considering historical data, and in a longer perspective of stable market development, such a strategy seems reasonable.

Fig. 5 shows the plots of the ACF and PACF functions drawn for the second sub-series extending from July 2003 until November 2008.

The number of non-zero elements in the ACF plot extends to 15 lagged samples, which specifies the order of the MA process and the length of the system input memory (the influence of an agglomerate independent variable). In contrast, the PACF plot exhibits first-order AR process, with continuously increasing mean and large variance. The observed pricing mechanism can be attributed to a random walk process in search of a new equilibrium state. The reason is that the housing market follows qualitative changes occurring in its economic environment. In such times of an unprecedented housing bubble, previous transaction prices cease to matter and the current pricing mechanism becomes dominated by the history of independent random variables altering the whole economic environment. Quasi-discrete transitions between equilibrium states erase the output memory, hence information from the environment can help in anticipating future behavior of the market during the period of its turbulent development.

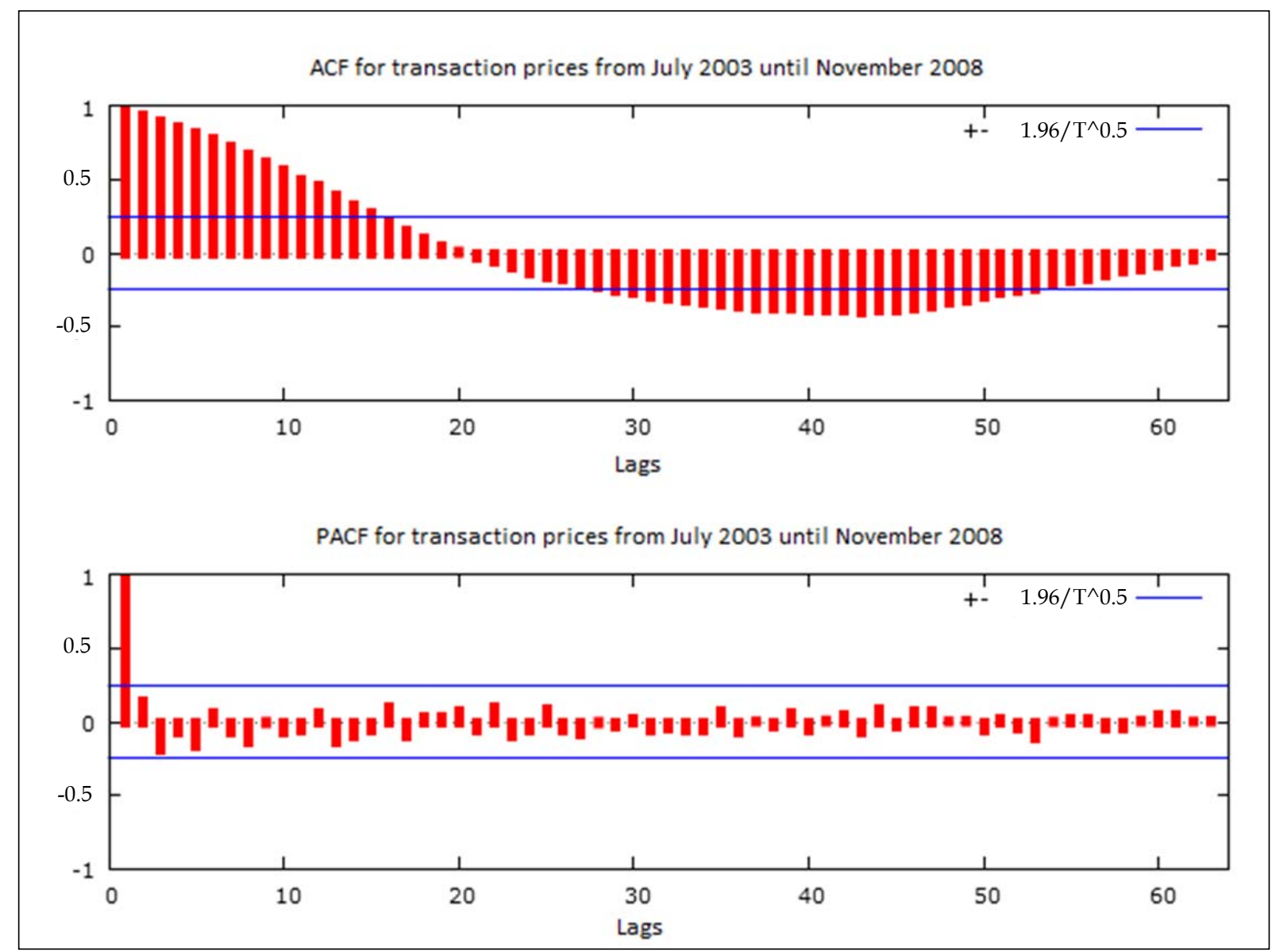

Fig. 5. Plots of the ACF (upper) and PACF (lower) functions in the second range from July 2003 until November 2008. Source: own study.

Fig. 6 shows the plots of the ACF and PACF functions for the third sub-series extending from December 2008 until December 2011.

As in the first sub-series (Fig. 4), extracted housing prices form a stationary sequence. Despite the fact that both AR and MA values point to the zero-order processes, the formal description of the pricing mechanism mostly coincides with that of the first subseries. After euphoric rises in transaction prices, the housing market settles down at a new equilibrium level, with a reduced contribution of earlier entries of the independent variable to the current stage of stable development. 


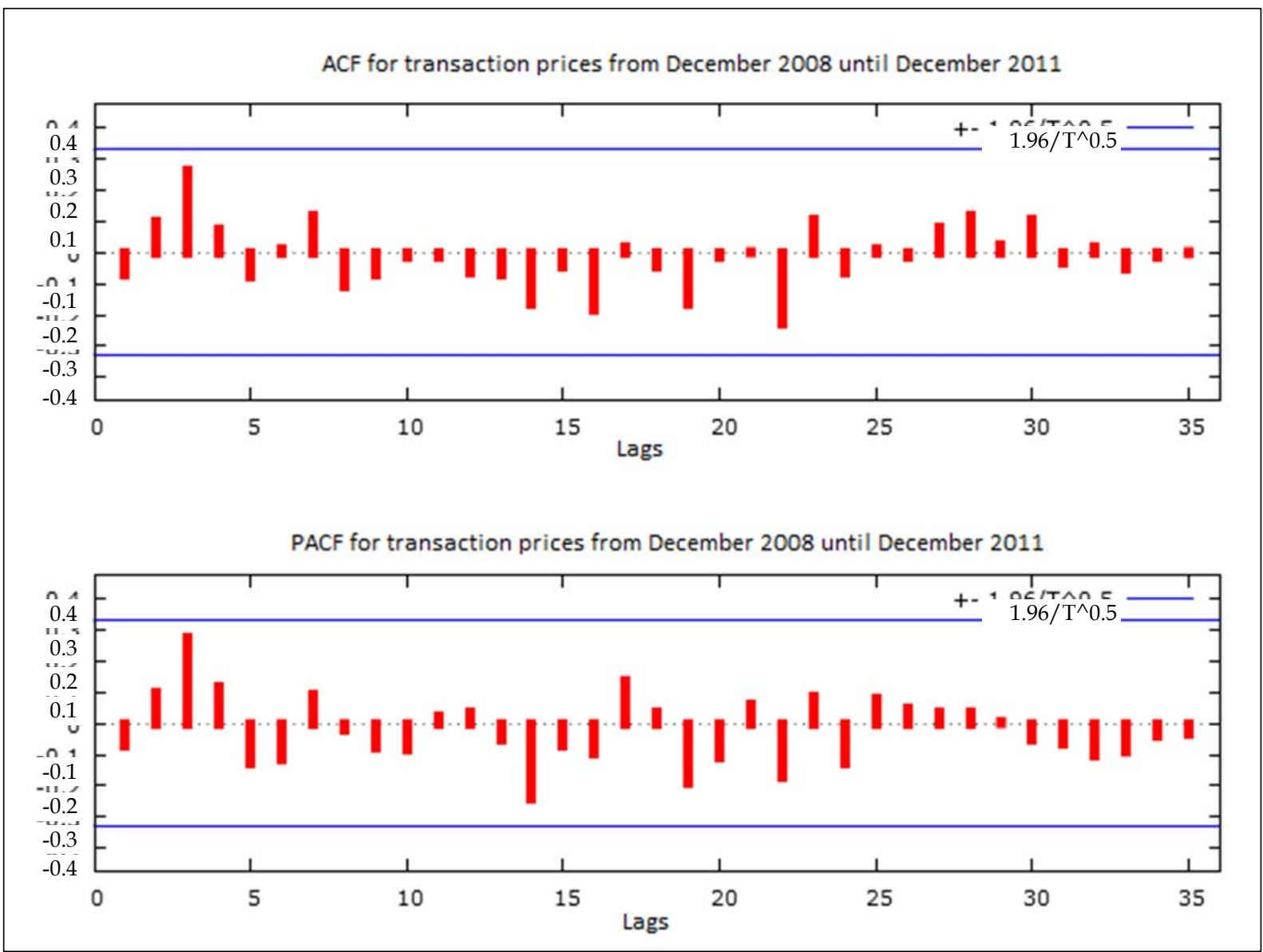

Fig. 6. Plots of the ACF (upper) and PACF (lower) functions for the third sub-series from December 2008 until December 2011. Source: own study.

\section{Conclusions}

Time series of housing prices studied in the period from 2001 until 2011 are samples of a stochastic process with a non-stationary mean and variance. Discrimination between stationary and nonstationary regimes is assessed using the autocorrelation (ACF) and partial autocorrelation (PACF) functions. This procedure caused the entire time series to be split into three separate sub-series corresponding to intertwined dynamical processes. The suggested pattern of the evolution mechanisms takes the form: A/B/A, where:

1. A - is referred to long-term, stable (laminar) evolution of the market with a short-term system memory that produces a stationary time series of housing prices,

2. B - is referred to short-term, quasi-discrete (turbulent) changes in market stability with a longterm memory of independent input variables that generates a non-stationary sequence of housing prices.

\section{References}

ADAMCZEWSKI Z., 2002, Nieliniowe $i$ nieklasyczne algorytmy w geodezji (Non-linear and Non-classic Algorithms in Geodesy), Oficyna Wydawnicza Politechniki Warszawskiej, Warszawa.

Belaire-Franch, J., OpOnG, K. K., 2013, A Time Series Analysis of UK Construction and Real Estate Indices. The Journal of Real Estate Finance and Economics, 46(3), pp. 516-542.

BITNER A., 2003, Wskaźniki wzrostu cen nieruchomości gruntowych dla dużych rynków lokalnych (Land Real Estate Price Increase Indicators for Large Local Markets), Materiały III Konferencji NaukowoTechnicznej PSRWN, Gdańsk.

BRZESZCZYŃSKI, J., KELM, R., 2002, Ekonometryczne modele rynków finansowych: modele kursów giełdowych $i$ kursów walutowych (Econometric Models of Financial Markets: Models of Market Rates and Currency Rates), WIG-Press. 
BRZEZICKA, J., 2013, Sezonowość rynku nieruchomości (Seasonality of the Real Estate Market), Świat nieruchomości (World of Real Estate), 2 (84), pp. 26-31.

BUDZYŃSKI T., 2010, Metodyka aktualizacji cen na przykładzie nieruchomości lokalowych (Methodology of Updating Prices on the Example of Local Real Estate), Studia i Materiały Towarzystwa Naukowego Nieruchomości , Vol. 18(1), pp. 107-118

CELlmeR R., 1999, Propozycja procedury wyceny nieruchomości metoda analizy statystycznej rynku (Proposition of Procedure of Valuating Real Estate Using the Method of Market Statistical Analysis), Wycena-Obrót-Zarządzanie, 6 (47).

CHATFIELD C., 1975, The Analysis of Time Series: Theory and Practice, Chapman and Hall .

CzAJA J., 2001, Metody szacowania wartości rynkowej i katastralnej nieruchomości (Methods of Estimating Market Value and Cadastral Value), Wydawnictwo KOMP-SYSTEM, Kraków.

DiTTMAN I., 2012, Lokalne rynki mieszkaniowe w Polsce - podobieństwo pod względem zmian cen transakcyjnych oraz dostępności mieszkań (Local Housing Markets in Poland - Similarity in Terms of Changes in Transaction Prices and Availability of Housing), Studia i Materiały Towarzystwa Naukowego Nieruchomości, Vol. 20, No. 1, pp. 71-90.

DitTmanN, I., 2013, Primary and Secondary Residential Real Estate Markets in Poland-Analogies in Offer and Transaction Price Development, Real Estate Management and Valuation, 21(1), pp. 39-48.

DOMAN, M., Doman, R., 2004, Ekonometryczne modelowanie dynamiki polskiego rynku finansowego (Econometric Modeling of the Dynamics of the Polish Financial Market), Prace Habilitacyjne/Akademia Ekonomiczna w Poznaniu, 15.

DrACHAL K., 2014, Property Prices and Regional Labor Markets in Poland, Singidunum Journal of Applied Sciences 11(1), pp. 5-15.

FORYŚ, I., 2010, Apartment Price Indices on the Example of Cooperative Apartments Sale Transactions, Folia Oeconomica Stetinensia, 9(1), pp. 72-82.

Goetzmann, W. N., Peng, L., \& Yen, J., 2012, The Subprime Crisis and House Price Appreciation, The Journal of Real Estate Finance and Economics, 44(1-2), pp. 36-66.

HOZER J., 1999, Wykorzystanie wyników analiz statystycznych rynku nieruchomości do szacowania nieruchomości (Exploitation of the Results of Statistical Analysis to Estimate the Real Estate Market Value), Zeszyty Naukowe Uniwersytetu Szczecińskiego, Nr 233, Prace Katedry Ekonometrii i Statystyki, Szczecin.

KОКОт, S., 2014, Teoretyczne i praktyczne problemy wyznaczania indeksów cen nieruchomości (Theoretical and Practical Problems of Determining the Price Indices ), Studia i Prace Wydziału Nauk Ekonomicznych i Zarządzania/Uniwersytet Szczeciński, 36, Vol. 2, pp. 287-304.

LANGE O., 1975, Ekonometria (Econometrics), Polskie Wydawnictwo Ekonomiczne, Warszawa.

KENDALL M., 1976, Time Series, Charles Griffin.

MiLl J.S., 1965, Zasady ekonomii politycznej i niektóre jej zastosowania do filozofii społecznej (The Principles of Political Economy and its Certain Applications in Social Philosophy) , PWN, Warszawa (PWN, Warsaw) [w:] [in:] FAŁDA B., 2010, Modelowanie dynamiczne procesów ekonomicznych (The Dynamic Modeling of Economic Processes), Wydawnictwo KUL, Lublin (Catholic University of Lublin Publishing House, Lublin)

Milo W., 1990, Szeregi czasowe. (Time Series), Państwowe Wydawnictwo Ekonomiczne, Warszawa.

RABIEJ M., 2012, Statystyka z programem Statistica (Statistics with the Program Statistica), Wydawnictwo Helion, Gliwice.

SZAFRAŃSKI G., 2015, Metody i analizy prognozowania szeregów czasowych (Methods for Forecasting and Time Series Analysis ), http:/ /gszafranski.w.interia.pl/FinEcon/Szeregi\%20czasowe.pdf.

TrojaneK R., 2013, An Attempt to Identify the Seasonality of Housing Prices in the Selected Cities of Poland in 1996-2012, Real Estate Management and Valuation, Vol. 21, No. 4, pp. 96-103.

ZELIAŚ A., 1984, Teoria prognozy (The Theory of Forecasts), Polskie Wydawnictwo Ekonomiczne, Warszawa.

RENigIER-BIŁOZOR M, WiŚNIEWSKI R., BiŁOZOR A., KAKLAUSKAS A., 2014, Rating Methodology for Real Estate Markets - Poland Case Study, International Journal of Strategic Property Management, Vol. 18. Issue 2, pp. 198-212. 